\title{
Teaching Biology through Communication and Design, and Public Health Challenges, in Pakistan
}

\author{
Humaira Qureshi, Gulraiz Khan, Javeria Samad \\ Habib University, Pakistan
}

\begin{abstract}
In order to reduce the disease burden in developing countries, contribution from all fields of study are required. Therefore, students who are not majoring in biology need to develop a basic understanding about health and disease, so they can also play a role in curbing this problem. Habib University is one of its kind liberal arts school in Pakistan that encourages students to increase their breadth of knowledge in various disciplines. An elective course, Cell Biology and Communication Design in Public Health, was designed at Habib University to impart basic information about cell biology and connect it with diseases at an individual and societal level. Students also developed communication design skills to create innovative strategies and communication artefacts. The aim of these communication pieces was to create awareness about the prevalent diseases, avail preventive/treatment options, and remove societal stigmas so treatment could be sought at an earlier stage.
\end{abstract}

\section{Introduction}

Global health is one of the top priorities for achieving world economic stability [1]. Despite best efforts, health conditions in developing countries remain subpar, leading to a persistently high disease burden. In 2015, for instance, the infant mortality rate (the number of deaths of children less than one year of age) for Pakistan rested at 65.8 (per 1,000 live births) according to the World Bank. A lowincome country with a large and growing population, Pakistan continues to suffer excessively from inadequate public health systems and resources. To curb the public health crisis, it is not enough to create doctors, nurses or technical staff. It is necessary to include members from other disciplines like policy makers, software developers, and communication designers so they can play their part in eradicating disease by raising awareness and contributing to policy decisions about interventions to control diseases.

To that end, this course was designed to provide human health related biological information to students who are not majoring in biology. Students also developed skills to communicate this information to the public without compromising on the underlying scientific knowledge. Bringing together different disciplines to raise public awareness and to disseminate information on handling/preventing disease conditions should help reduce the disease burden in Pakistan.

\section{Scientific culture}

The course followed the principle of scientific culture proposed in Science editorial [2]. Scientific culture includes scientific education and community outreach. It is imperative to incorporate a scientific culture in the developing nations' societies to dispel misinformation about health issues, primarily because most public health issues in Pakistan, such as Polio, Tuberculosis, Hepatitis, malnutrition etc., are not scientific challenges, but more often sociocultural challenges. Cultural beliefs, bias and unfounded notions lead to the prevention of eradication of diseases. There is a misconception among poor Pakistani population that Polio vaccination may lead to sterility in children [3]. As one of the last 3 countries left in the world with incidence of Polio, the socio-cultural challenge has been far more difficult to deal with, despite the availability of a vaccine. Such baseless beliefs can only be dispelled by escalating efforts to expand education and creating a scientific culture.

\subsection{Role of Communication \& Design}

Expanding education and inculcating a scientific culture vis-à-vis public health issues is a complex societal challenge that needs examination from a lens beyond that of natural science. Rittel and Webber 
talked about such challenges in early 1970s from a design perspective. The inherent 'wickedness' of these challenges, they argued, is because of the changing, pluralistic nature of the society where indisputable notions of public good were becoming increasingly difficult to agree upon. Empirical, scientific approach to problem solving had served the society well for decades, especially as it improved the quality of life for people, but was increasingly being attacked during the volatile decade they were writing in. These wicked problems required a completely different mindset, and tools, from their tame counterparts, they argued. Their diagnosis, however, was restricted to what they called "societal problems" that planning dealt with, such as urban regeneration, income inequality, welfare programs and so on. For them, "scientists and perhaps some class of engineers" still dealt with solvable, "tame" problems [4].

Polio, which proved to be a "tame" problem in most countries of the world from where it has been eradicated, has proven to be quite a "wicked" problem in Pakistan. Despite awareness, parents have routinely refused to get children vaccinated, and polio teams have come under violent attacks, leading to loss of life of the health workers [5]. An indisputable notion of public good, i.e. eradication of Polio, has become difficult to agree upon by some fringe groups, threatening the resurgence of the disease not just in Pakistan, but also its spread to other parts of the world. This challenge is not exclusive to Pakistan and Polio. The rise of antivaccination sentiment, against scientific evidence, and flamed by conspiracies linking vaccination to autism, has led to a resurgence in the cases of measles in United States, with a record 667 cases from 27 states reported to CDC's National Center for Immunization and Respiratory Diseases [6]. Viruses have gone from being a scientific challenge, to a socio-cultural one.

Communication, therefore, provides an additional tool to examine the complex public health challenges. This conjecture is not without evidence: a key tool used by the Global Polio Eradication Initiative, a public-private partnership led by national governments and spearheaded by the World Health Organization, Rotary International, the US Centers for Disease Control and Prevention, and the United Nations Children's Fund, is Rhizome, an “online resource [...] designed to support the endgame of global polio eradication by bringing together quality guidance, tools and standards for polio Communication for Development (C4D) strategies" [7]. The global focus on communication strategies has been evident in the current polio eradication campaign in Pakistan, with an emphasis on personal testimonies for advertising campaigns, particularly from religious leaders, and a coherent visual identity for the vaccination teams and their equipment, to build trust in the repeated campaigns, after several setbacks and scandals involving expired vaccinations [8].

Design, through the Human-Centred Design and Design Thinking methodology, has also been increasingly used to address complex, endemic problems through innovative solutions, particularly in the global south. These additional lenses, therefore, were combined with knowledge of cell biology to examine public health issues in a local context for this class.

\section{Student Assortment in Class}

Habib University is Pakistan's first liberal arts and sciences undergraduate university. It offers majors in 4 disciplines: Social Development and Policy (SDP), Communication and Design (CND), Computer Science (CS) and Electrical Engineering (EE). SDP and CND come under School of Arts, Humanities and Social Sciences while CS and EE come under School of Science and Engineering. As a liberal arts institution, Habib encourages students to increase the breadth of their knowledge, through a common liberal core, and three programs that offer minors in Integrated Sciences and Mathematics, Languages and Literature, and Comparative Liberal Studies. Open electives are offered in various disciplines, particularly the minor programs, and the course in Cell Biology and Public Health was one such elective.

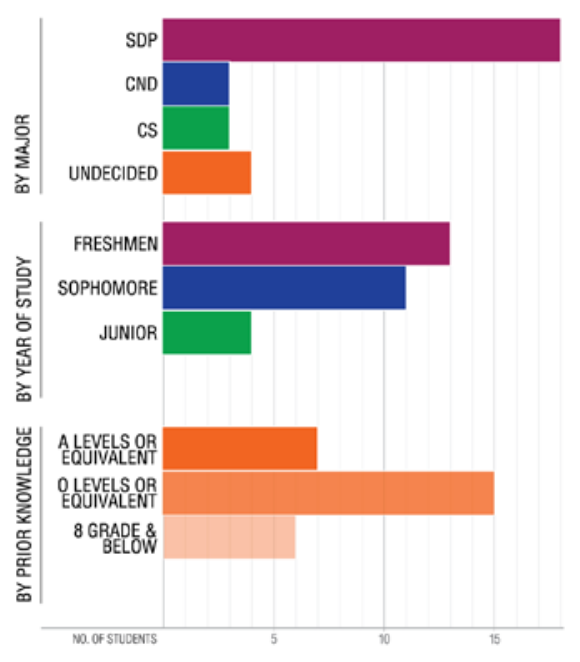

Figure 1. Composition of class, by majors, year of study, and prior knowledge 
A total of 28 students from three different majors attended the course. The following figure shows the class composition by majors, by year of study, and by prior knowledge of biology.

The course was offered as a freshmen-level elective but had a large number of sophomores and juniors in attendance too. The majority of students came from the Social Development and Policy major, but students from Computer Science and Communication and Design joined in too. At least four students had not declared their majors at the time of attendance.

\subsection{Unique distribution based on prior knowledge}

Prior knowledge of biology provided the most diversity and proved to be a challenge to satisfy each category. The students with least exposure to biology found it difficult to cope while those with prior knowledge caught on fast. As it happens, this is a common occurrence among biology courses for nonmajors as some students take advance placement biology in high school (based on their interest) while others having had poor science classes often arrive with a negative attitude bordering on intimidation and uncomfortable with their science skills [9].

Best solution was to pair students having limited knowledge of biology with those having some command in the subject, so they could help each other.

\section{Course Content}

As a 100-level course with students from a variety of disciplines and varying background in biology at the secondary and high school level, the cell biology component in the course was kept to a basic level [10]. Briefly, it included prokaryotic and eukaryotic cells, cell organelles, cell structure function, mitosis and meiosis and cancer, DNA and genetic mutations, Mendelian genetics and $\mathrm{ABO}$ blood grouping system and the immune system. Each component was linked with the final outcome/symptom of disease, so students could link the impact from cellular level to the body as a whole. For example, Mendelian genetics was taught in terms of Thalassemia, a disease quite prevalent in Pakistan. Then students were introduced to the basics of public health and epidemiology, so they could further link the disease to the society as a whole. Communication design element was introduced with reference to two contextually relevant public health problems - the polio vaccination, and the dengue virus infections. Students looked at the problem across all scales from the individual cellular level, to the global scale of fighting these persistent health concerns. Students got to develop a better understanding of communication strategies through a final project.

Apart from general text book readings, articles from newspapers, magazines and journals were included to facilitate students with weaker backgrounds.

\section{Course co-teaching}

This course was designed to be a team taught interactive effort. Two instructors, each with specialized knowledge either in Cell Biology or Communication Design, built this course from scratch. Since each instructor belonged to a different school at the university (the School of Arts, Humanities and Social Sciences or the School of Science and Engineering), this course was unique in its offering and especially appealing to students from both the schools. Though interdisciplinary teaching has its own sets of challenges, it is rewarding when students from different academic fields of study come together to offer integrative solutions.

Each instructor had well defined roles with proportionate distribution in the syllabus. The lead instructor was responsible for student attendance, enrollment, assignment/quiz/exam marks, uploading lectures on the student webs and determination of final grades.

\section{Course Assessments}

Course was assessed based on the following criteria:
a) Quizzes (15\%)
b) Assignments (15\%)
c) Class participation (5\%)
d) Mid-term (20\%)
e) Final Project (30\%)
f) Final Exam (15\%)

Students were assigned four quizzes and two assignments. One of the quizzes was a take home quiz while another was Immediate Feedback Assessment Technique (IF-AT) based quiz.

Assignments included creating a 3D model for the cell and making a flyer for a disease of interest showing the disease mechanism right down to the cellular level.

\section{Final Project}

The final project, titled Communication/Design for Public Health, was an investigation, and a proposition, into an existing area of public health concern. Students, either individually or in pairs, had 
to identify an existing public health issue - a virus, a disease, or any predominant medical condition relevant to the context of Pakistan. They also had to identify at least one key stakeholder for this topic - a relevant practitioner, a hospital, a medical facility that specializes in this, or a patient. Building their knowledge on relevant desk research, students had to design a questionnaire and interview two stakeholders. After discussing about the gaps in the existing strategy (prevention or cure) and the communication artefacts (pamphlets, ads, radio or television spots, websites, etc.), students had to (re)design a communication strategy and come up with a new artefact. Their final outputs were in three forms:

1. An A-3 poster that contextualized the topic. The poster was constructed in Adobe InDesign. It covered a quick scientific explanation of how the disease works, with an original cellular sketch to show the disease mechanism at the cellular level, the incidence of the disease/virus globally or in Pakistan, how it spreads, and what's the existing communication strategy. The students then proposed a new strategy, mentioning all the components, their tone and the visual language.

\section{Public Health Issue}

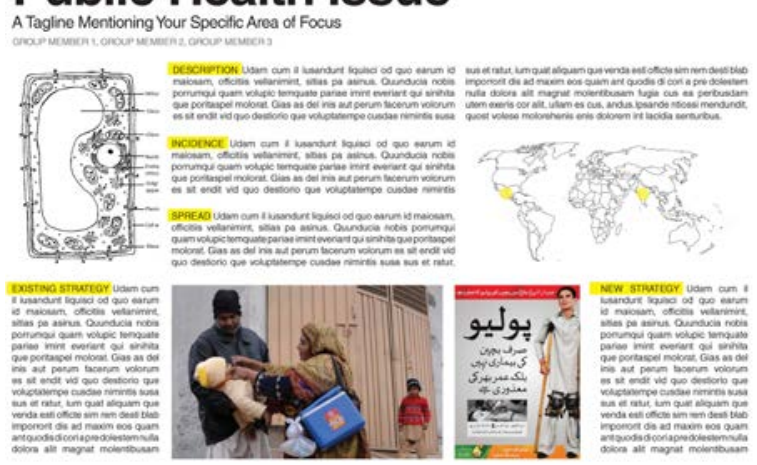

Figure 2. Sample poster layout

2. An artefact that's representative of the new strategy - students had the option to make a new pamphlet/poster/radio ad/30-sec TV ad/website etc. The artefact showed the redesigned components of their new strategy in action.

3. A written, 1000-word report about their process, explaining how they arrived at these outputs, and how they are more effective than existing ones. Table 1 shows the different diseases that the students chose to work on and the various communication artefacts that they adopted for the new strategy.

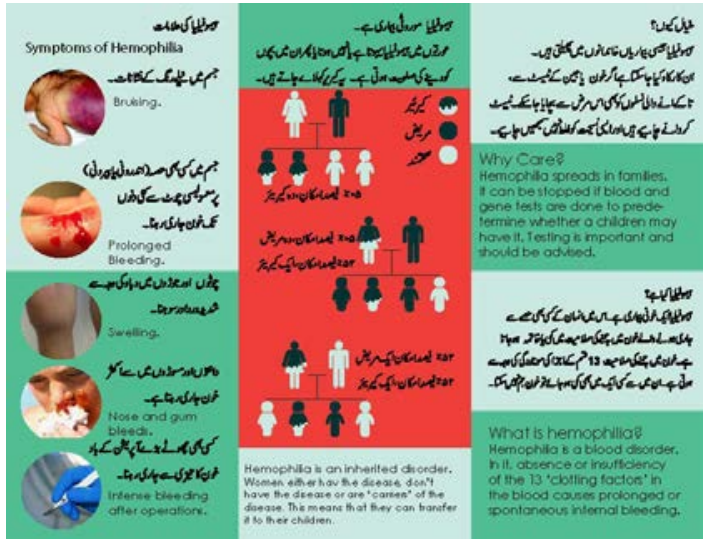

Figure 3. The inside of a student-designed, bilingual pamphlet on Hemophilia

Table 1. Diseases with relevant artefacts designed as part of new communication strategy

\begin{tabular}{|c|c|}
\hline Disease & Communication Artefact \\
\hline Diabetes Type 1 & Pamphlet for awareness \\
\hline Thalassemia & $\begin{array}{l}\text { Facebook page "Students } \\
\text { against thalassemia" }\end{array}$ \\
\hline $\begin{array}{l}\text { Chronic Kidney } \\
\text { Disease }\end{array}$ & $\begin{array}{l}\text { Phone hotline (interactive voice } \\
\text { response) }\end{array}$ \\
\hline Breast Cancer & $\begin{array}{l}\text { Video for breast cancer self- } \\
\text { check }\end{array}$ \\
\hline Tuberculosis & Radio ad in national language \\
\hline Diabetes Type 2 & Meal plan pamphlet \\
\hline Naegleria & Radio ad in national language \\
\hline Oral Cancer & Video for awareness \\
\hline Breast Cancer & $\begin{array}{l}\text { Website for awareness with } \\
\text { chat room for patient support }\end{array}$ \\
\hline Emphysema & $\begin{array}{l}\text { Poster for awareness in national } \\
\text { language }\end{array}$ \\
\hline Thalassemia & $\begin{array}{l}\text { Poster to increase blood } \\
\text { donation }\end{array}$ \\
\hline Hemophilia & Pamphlet for awareness \\
\hline Alzheimer & Video for awareness \\
\hline HIV & Radio ad in local dialect \\
\hline Gastric ulcers & $\begin{array}{l}\text { Poster for awareness and } \\
\text { treatment options }\end{array}$ \\
\hline Hepatitis B & Pamphlet for awareness \\
\hline
\end{tabular}

\section{Active Learning Approaches}

Extra effort had to be put in to keep the students engaged and motivated since this was an elective class. Class activities, videos and memes were included in the lecture and relevant movies were 
recommended to keep the students' interest alive. Students were provided with worksheets to emphasize key concepts and help them practise the new skill gained in the class.

\subsection{Use of software, Socrative}

Socrative (a cloud-based student response system that allows students to respond to questions using their smartphones) was employed to gauge understanding from students at the individual level. It allowed for students to reaffirm the answers in class without having to own up to their mistakes as the software allows them to answer questions anonymously as well. This also benefited the teacher to ascertain the level of understanding exhibited from the class after explaining a certain topic, so measures could be taken to reinforce the concept if necessary.

\subsection{Videos by the Amoeba Sisters}

Videos from the "Amoeba Sisters" were quite popular amongst the students with limited prior knowledge of biology as their explanation methods were quite humorous and compelling, explaining advanced topics in an accessible manner. Videos also had related worksheets to enforce the concept [11].

\subsection{Mitosis and Meiosis simulation lab kit}

A commercially available lab kit from Fisher Scientific was utilized for a hands-on activity by students in order to convey the concept of mitosis and meiosis. Student got to construct models using colored pop beads to illustrate chromosome structure and function such as genetic recombination, crossing over and chromosomal aberration. Students specially enjoyed this activity as it cleared up the major differences between the two modes of cell division in a fun manner [12].

\subsection{Creating a 3D model of the cell}

As part of an assignment the students had to create a 3D model of the cell using any material that they deemed appropriate. One of the students created an edible model using a cake as the main body of the cell and different icings to generate the cell components. Another used a cantaloupe as the main cell body with carved insides for playdoh-based cell component suspended in jelly as the cell cytoplasm. One more group used their skills from the engineering workshop to design a unique model of the cell using wood pieces.

\subsection{Hands-on lab activities}

Students were provided the opportunity to test their ABO blood groups in class with a short handson exercise. This was specifically exciting for some students as they never knew that finding out their blood group was such as easy task. Some students were hesitant to prick themselves, so this activity was kept optional. Students were also briefed on the importance of sterile handling techniques and appropriate disposal of biological waste.

While studying about DNA, the students got to isolate cellular DNA from pea extract and thus having visualized the DNA, it helped to hold the students' interest in all DNA related theoretical work.

\subsection{Use of IF-AT for quiz}

The Immediate Feedback Assessment Technique (IF-AT), is a stimulating and revolutionary new testing system that transforms traditional multiplechoice testing into an interactive learning opportunity for students [13]. It enables students to get immediate feedback on the accuracy of their answers, whether they are right or wrong, and the opportunity to try again if the answer is incorrect. Thus, the IF-AT teaches while it assesses.

\subsection{Adobe InDesign training}

To strengthen poster designing skills, the students also received hands on introductory training for Adobe InDesign, a desktop publishing software application used for creating posters, flyers and brochures.

\section{Student Performance}

Students received grades based on the following criteria:

$$
\begin{aligned}
& A=90 \text { or above } \\
& B+=80 \text { or above } \\
& B=70 \text { or above } \\
& C=60 \text { or above }
\end{aligned}
$$

According to performance based on majors, it was noticed that most students achieved a $\mathrm{B}+$ grade irrespective of the major they were enrolled in (see Figure 4).

According to performance based on prior knowledge of biology, students with background in A Level biology (and the local board equivalent) fared better than other students. All students from a background in $\mathrm{O}$ levels received a $\mathrm{B}+$ or lower grade. The same was true of students who had last 
encountered biology in $8^{\text {th }}$ grade or below (see Figure 5).

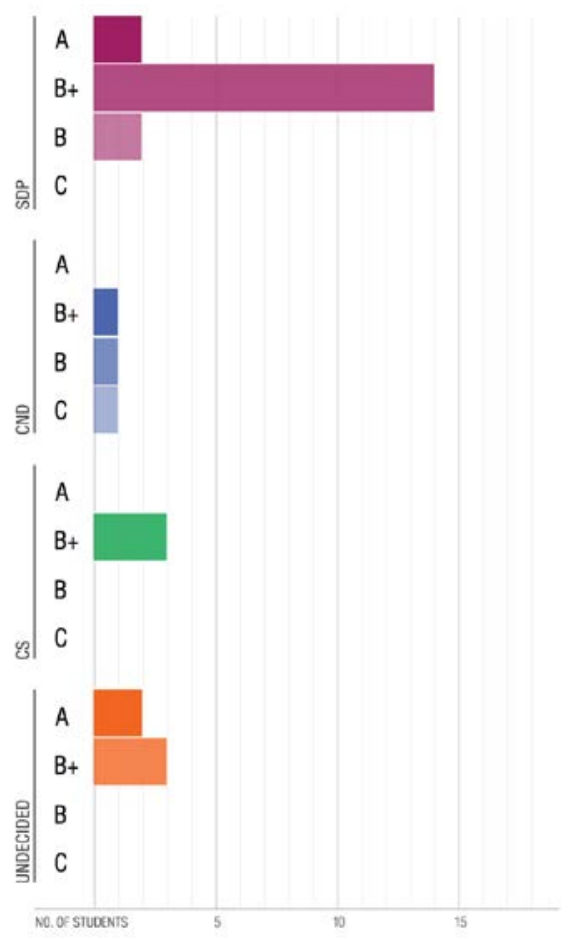

Figure 4. Number of students with grades achieved, distributed on the basis of enrolled majors

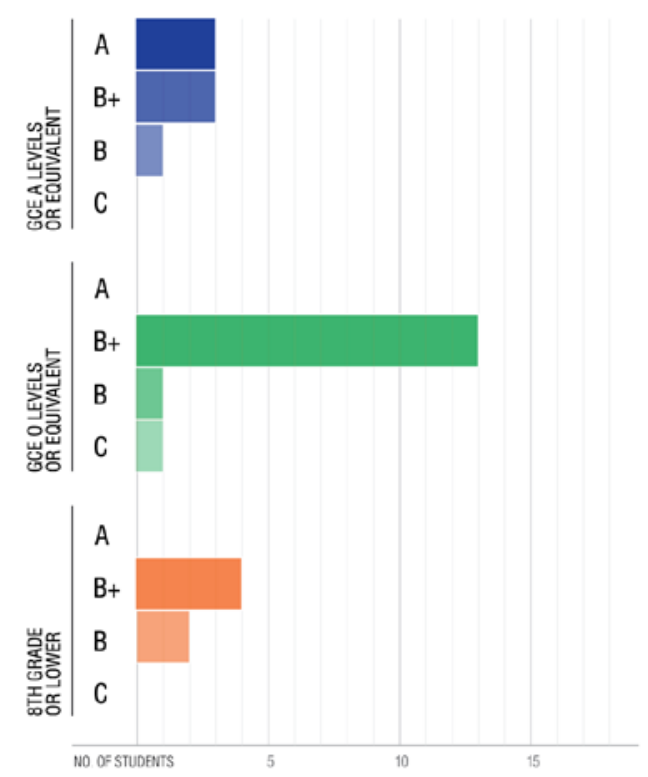

Figure 5. Number of students with grades, distributed on the basis of prior knowledge

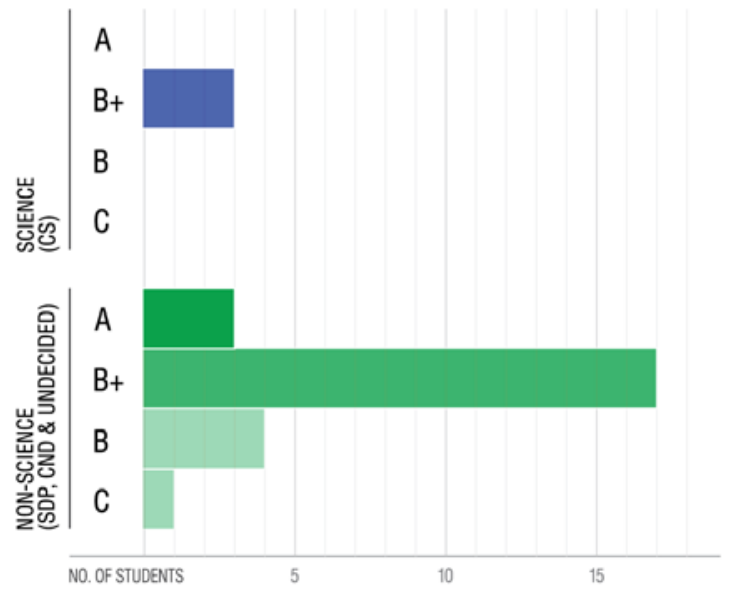

Figure 6. Number of students with grades, distributed on the basis of prior knowledge

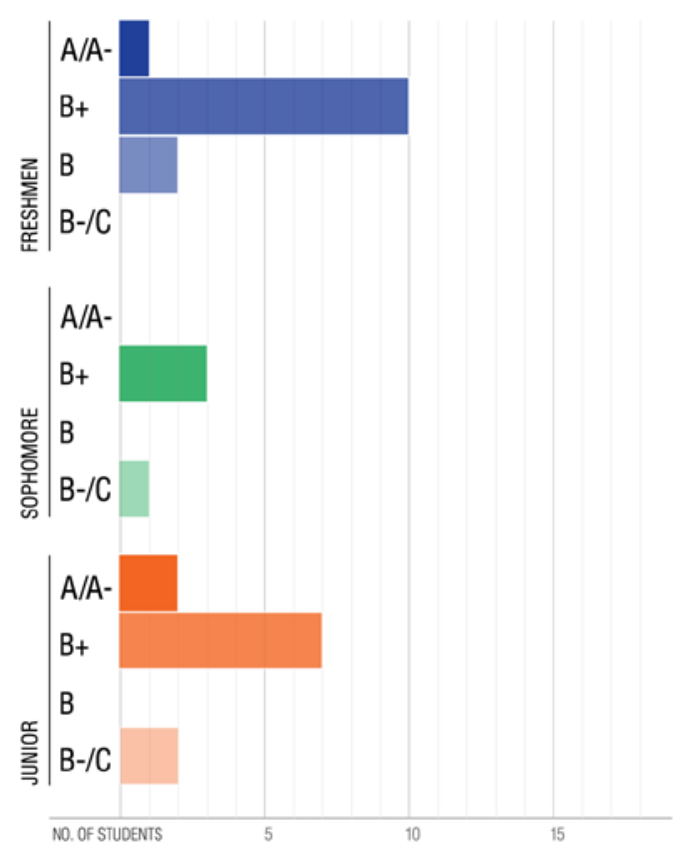

Figure 7. Number of students with grades achieved distributed on the basis of year of study

A majority of students in class came from nonScience or undeclared majors. However, their affiliation did not affect their grades. They performed as well, and better, than their Science counterparts (see Figure 6).

Freshmen students were anticipated to perform below sophomore and junior students because first year grades do not contribute to their overall GPA according to university policy. However, that was 
not the case. Both, first year students and advanced students (sophomores and juniors) performed equally well in the class (see Figure 7).

Table 2. Evaluations of course from students $(n=8)$. Maximum rating was 5. Rating Scale: 1 is Strongly Disagree, 5 is Strongly Agree

\begin{tabular}{|l|c|}
\hline \multicolumn{1}{|c|}{ Criterion } & $\begin{array}{c}\text { Rating } \\
\text { (average) }\end{array}$ \\
\hline $\begin{array}{l}\text { The syllabus clearly stated course } \\
\text { and learning outcomes }\end{array}$ & 4.13 \\
\hline $\begin{array}{l}\text { The material presented in the course } \\
\text { was consistent with the syllabus }\end{array}$ & 4.13 \\
\hline $\begin{array}{l}\text { The material presented in the course } \\
\text { increased my knowledge of the } \\
\text { subject }\end{array}$ & 4.0 \\
\hline $\begin{array}{l}\text { Assignments helped to increase my } \\
\text { knowledge and confidence in the } \\
\text { subject }\end{array}$ & 3.38 \\
\hline $\begin{array}{l}\text { The material presented in the course } \\
\text { was engaging for the students }\end{array}$ & 3.75 \\
\hline $\begin{array}{l}\text { The course provided knowledge and } \\
\text { tools I will use in the future }\end{array}$ & 3.5 \\
\hline $\begin{array}{l}\text { The course challenged me in ways } \\
\text { that encouraged intellectual growth }\end{array}$ & 3.38 \\
\hline
\end{tabular}

\section{Student learning through field work}

For the final project, students had to find relevant stakeholders and interview them. The student group working on Thalassemia encountered two NGOs working on Thalassemia, both of which had lost patients to the disease and that is why they were driven to combat it. Very little work was being done at the government level. Most affected families were unaware of the risk that intermarriages bring for Thalassemia and there were many children in the same family affected with the disease. Hence, our students devised a strategy to get all students at university level to get tested, therefore, they would know their status before marriage and lower the incidence of Thalassemia this way. Their Facebook page, "Students against Thalassemia", is now functional and the drive for Thalassemia testing at the university will start next semester.

Another group working on AIDS interviewed a village woman who had contracted HIV from her husband and had transmitted it to both her children at birth. After the death of the husband, the family had ostracized her and she was upset that she was completely unaware of the dangers of contracting HIV and the taboo that surrounds it. This group made a radio ad in the village's local dialect, explaining ways to prevent HIV contraction and how unsuspecting housewives were not to be blamed.
A third group working on Breast Cancer learnt about how women are ashamed/embarrassed to talk about lumps in the breast and hence delay seeking treatment leading to advanced stage of the disease. This group made a website where women could communicate with other patients/doctors and read about survivor stories to move past the stigma associated with breast cancer.

\section{Course evaluations}

Course evaluations were carried out through the Center for Pedagogical Excellence at Habib University. The overall response rate was twenty seven percent which is on the lower side, given it was exam season for the students and the course evaluations are not mandatory for them.

Table 3. Evaluations of instructors from students $(n=8)$. Maximum rating was 5. Rating Scale: 1 is Strongly Disagree, 5 is Strongly Agree

\begin{tabular}{|l|c|}
\hline \multicolumn{1}{|c|}{ Criterion } & $\begin{array}{c}\text { Rating } \\
\text { (average) }\end{array}$ \\
\hline $\begin{array}{l}\text { The clearly } \\
\text { communicated the syllabus, } \\
\text { objectives and learning outcomes of } \\
\text { this course. }\end{array}$ & 4.5 \\
\hline $\begin{array}{l}\text { The instructor was prepared for } \\
\text { class }\end{array}$ & 4.63 \\
\hline $\begin{array}{l}\text { The instructed presented course } \\
\text { material in an organized fashion }\end{array}$ & 4.63 \\
\hline $\begin{array}{l}\text { The instructor stimulated my } \\
\text { interest in the course }\end{array}$ & 4 \\
\hline $\begin{array}{l}\text { The instructor showed respect } \\
\text { towards students }\end{array}$ & 5 \\
\hline $\begin{array}{l}\text { The instructor encouraged class } \\
\text { participation }\end{array}$ & 4.75 \\
\hline $\begin{array}{l}\text { The instructor was available during } \\
\text { specified office hours }\end{array}$ & 4.75 \\
\hline $\begin{array}{l}\text { The instructor provided timely } \\
\text { feedback on tests, } \\
\text { reports, projects, and other } \\
\text { assignments }\end{array}$ & 4.5 \\
\hline $\begin{array}{l}\text { The instructor provided reasons for } \\
\text { grades assigned to me }\end{array}$ & 4.38 \\
\hline
\end{tabular}

The details for the criteria used for course evaluation and their individual ratings are given in Table 2.

Instructor evaluations were also carried out in the same format. The two instructors were not evaluated separately which is something that can be modified the next time the course is undertaken. Table 3 shows the criteria for instructor evaluation and their individual ratings. 
As part of the evaluation form, students were allowed to give longer responses/comments to some open-ended questions which are shown in Table 4. There was positive as well as negative feedback all of which will help improve the course for the next offering.

\section{Future improvements}

This course still has a lot of room for improvement. The concentration on cell biology aspect can be reduced and more content on public health and design can be incorporated.

Table 4. Excerpts from student responses to open ended questions in the evaluation form $(n=8)$

\section{Please comment on what worked well for you in this course}

- The engaging and friendly environment of the class

- The discovery of broader perspective in terms of public health and awareness.

- Exposure to research material on international level

- The videos as resources aided in explaining the material, however there was a lot of information to digest altogether. The practice worksheets helped out a lot as well, as well as the project

Please comment on what aspects of the course could be improved

- Large amount of Research and Field Project burden

- The component of Public Health should be introduced in the beginning of the semester. So instead of giving the designing work towards the last weeks, it should be given in the beginning so students have more time to work on it

- More activities, not tests and quizzes but instrcutors' method of engaging the class was very helpful and effective

Lab tours can be arranged to demonstrate the application of the scientific concepts and to broaden the students' vision. Visits to public health departments can be beneficial as well. Based on students' feedback, the project work can be introduced earlier in the course so there is ample time for stakeholder interviews and feedback. Focus on exams as part of assessment criteria can be removed and replaced with practical assignments and more weightage for project work. More active learning tools can be integrated for generating interest in scientific fields.

Another important feature that we hope to include is the activity-based learning provided by a newly designed space at Habib University known as the Playground. It is part of Habib's Centre for Transdisciplinarity, Design \& Innovation. This newly renovated space contains essential elements to facilitate creative collaborative work. A major goal of the Playground is to remove barriers between various design and making facilities on campus and to facilitate faculty and student learning across disciplines. As such, the Playground, through its soft prototyping facilities, works as the gateway to all design and making facilities on campus, and is in the process of developing graduated curricula for all available skills. The space currently offers three dynamic zones for hosting workshops, pop-ups and studio sessions with flexible seating and working options.

\section{Conclusion}

The course intended to educate the basic concepts of human cell biology to the students, so they could develop a better understanding of diseases. The students were further trained to generate innovative ways to communicate health-related significant information to the common man without deviating from scientific facts. These communication pieces were intended to create awareness about the prevalent diseases, avail preventive/treatment options, or remove societal stigmas so treatment could be sought at an earlier stage. The analysis of final grade shows that while prior knowledge helped students in class (and reflected in higher grade bands), other factors (major, area of study and year of study) did not appear to have a decisive effect on their grades. The active learning methods, a focus on learning through field work, and contribution of nonbiological components towards the final grade all play a role in explaining the outcomes.

\section{Acknowledgements}

The Habib University provided support for the development of this study. We are grateful to both, the School of Science and Engineering, and the School of Arts, Humanities and Social Sciences, for encouraging collaborative efforts towards teaching and learning. 


\section{References}

[1] Report, "Top Ten Global Economic Challenges: An Assessment of Global Risks and Priorities”, Groupings global economic and development, 2007.

[2] B. Alberts, "Policy-making needs science", Science, AAAS, (New York, NY), 2010, 3;330 (6009), pp. 12871287.

[3] A.R. Khowaja, et al. "Parental perceptions surrounding polio and self-reported non-participation in polio supplementary immunization activities in Karachi, Pakistan: a mixed methods study." Bulletin of the World Health Organization, 2012, 90.11, pp. 822-830.

[4] H.W.J. Rittel and M.M. Webber, "Dilemmas in A General Theory of Planning," Policy Sciences 4, no.2, 1973, 155-169.

[5] "Pakistani polio workers under attack since 2012", The News International; https://www.thenews.com.pk/print/ 114664-Pakistani-polio-workers-under-attack-since-2012 (April 23, 2016).

[6] "Measles Cases and Outbreaks" Centers for Disease Control and Prevention. Centers for Disease Control and Prevention; https://www.cdc.gov/measles/cases-outbreaks. html (Access date: August 23, 2017).

[7] "Tools and guidance to help you design data driven communication strategies that help vaccinate every child”, Rhizome by GPEI; https://poliok.it/c4d (2017).

[8] “End Polio Pakistan"; http://www.endpolio.com.pk/ (Access date: August 15, 2017).

[9] Sarah E. Bondos and Dereth Phillips, (2008) "TeamTeaching a Current Events-based Biology Course for Nonmajors", Biochemistry and Molecular Biology Education, Vol. 36, No. 1, pp. 22-27.

[10] L. Arwood, "Teaching cell biology to nonscience majors through forensics, or how to design a killer course", Cell Biology Education, ASCB, 2004, 3(2), pp. 131-138.

[11] 'Science! With the Amoeba Sisters TM", http://www.amoebasisters.com/ (2013-2017).

[12] "Mitosis and Meiosis Lab Investigations", Fisher Scientific; https://www.fishersci.com/shop/products/ mitosis-meiosis-lab-investigations-3/p-2369235\#tab1 (2016).

[13] "What is the IF-AT?", Epstein Educational enterprises; http://www.epsteineducation.com/home/about/ (2016). 